$7-1-2014$

\title{
Remediation of NORM and TENORM Contaminated Sites-Review Article
}

\author{
R.O. Abdel Rahman \\ Atomic Energy Authority of Egypt \\ Mohamed Elmesawy \\ British University \\ I. Ashour \\ British University \\ Yung Tse Hung \\ Cleveland State University, y.hung@csuohio.edu
}

Follow this and additional works at: https://engagedscholarship.csuohio.edu/encee_facpub

How does access to this work benefit you? Let us know!

\section{Publisher's Statement}

This is the accepted version of the following article: Abdel Rahman, R. O., Elmesawy, M., Ashour, I., and Hung, Y.-T. (2014). "Remediation of NORM and TENORM contaminated sites-Review article." Environmental Progress \& Sustainable Energy, 33(2), 588-596., which has been published in final form at http://onlinelibrary.wiley.com/doi/10.1002/ep.11829/abstract

\section{Recommended Citation}

Rahman, R.O. Abdel; Elmesawy, Mohamed; Ashour, I.; and Hung, Yung Tse, "Remediation of NORM and TENORM Contaminated Sites-Review Article" (2014). Civil and Environmental Engineering Faculty Publications. 99.

https://engagedscholarship.csuohio.edu/encee_facpub/99

This Article is brought to you for free and open access by the Civil and Environmental Engineering at EngagedScholarship@CSU. It has been accepted for inclusion in Civil and Environmental Engineering Faculty Publications by an authorized administrator of EngagedScholarship@CSU. For more information, please contact library.es@csuohio.edu. 


\section{R. O. Abdel Rahman, Mohamed Elmesawy, I. Ashour, and Yung-Tse Hung}

INTRODUCTION

NORM and TENORM are generated in the form of by products, residues and wastes, from large scale industrial processes that exploit natural resources such as uranium min ing and milling, fertilizers production, and processing of metal and oil. Table 1 lists activities that lead to generation of NORM and TENORM from mineral ores extraction and indus trial processing [1 3]. The management of these materials is receiving considerable attention because of the large volumes of generated NORM, low specific activities, and very long lived radionuclides that exist due to natural radioactive decay of uranium and thorium decay series. In view of these fea tures, NORM/TENORM should be treated as a unique envi ronmental hazard, taking into account the national regulation and regional and international convention.

Historical NORM and TENORM management entailed land spread, surface impoundments and surface mounding. These practices have yielded in several soil, surface water and groundwater contamination problems [1]. It is worthy to note that contamination is defined as the presence of unwanted substance at concentrations above background, while pollution is contamination that results in or can result in adverse biological effects to resident communities [4]. To control these contaminants from spreading leading to greater pollution problems, there is a need to lunch a remediation program. Remediation programs are very costly, so the sup port of the decision making process to initiate such program for contaminated site has received great attention. Usually the decision is made based on two step assessments. At first, the contamination extent is identified by studying radionu clides dispersion pathways and mechanisms in soil surface, aquifers, groundwater, air, and surface water. Subsequently, land use, availability of natural resources in the site and fund availability are assessed. IAEA had defined radiological crite ria to support the remediation decision making process, this criteria is based on the definition of six bands for possible remediation situation each cover an order of magnitude in dose or risk [5,6]. Table 2 illustrates IAEA criteria for the beginning of remediation program for contaminated area [5]. The traditional approach to remediate soil contamination was based on removal and confinement, where contami nated groundwater was traditionally remediated using treat and pump technique [7]. Due to strengthen regulatory requirements, and expenses of these methods, new techni ques have been developed. The selection of appropriate technology is dependent on several technical and non technical factors. The technical factors include assessment of the ability of the technology to reduce risk to human health and the environment, reliability and maintenance require ments for the technology, available infrastructure to support the candidate technology, ease of accessing the technology and associated services, risk to workers and public safety during the implementation of the technology, environmental impacts of the technology, the ability of the technology to meet regulatory acceptance, and obtaining of community acceptance $[5,8]$. The above mentioned technical factors should be integrated in a structured approach to assess the decision making process to select appropriate technologies. Table 3 lists a technology evaluation matrix developed by IAEA; this matrix provides a subjective ranking scale for each factor [6],

Recently, green and sustainable remediation (GSR) has emerged as a beneficial approach to optimize all phases of site 
remediation, from site investigation to project closeout. Sustain able remediation was defined as a remedy or combination of remedies whose net benefit on human health and the environ ment is maximized through the judicious use of limited resour ces [9]. Environmental protection agency (EPA) identified five core elements of a GSR to assist with the selection of remedia tion technologies and approaches. These elements include [10];

1. Minimize total energy use and maximize use of renew able energy,

2. Minimize air pollutants and greenhouse gas emissions,

3. Minimize water use and impacts to water resources,

4. Reduce, reuse, and recycle material and waste, and

5. Protect land and ecosystems

In this work, the effort is directed to review advances in NORM and TENORM regulation in different countries, high light recent trends in remediation technologies and identify knowledge gaps.

\section{RECENT ADVANCES IN THE REGULATION OF NORM TENORM}

IAEA had indicated that the regulators and operators are facing a variety of new challenges with NORM regulations, these challenges are attributed to the nature of traditional industries and their capabilities to deal with radioactive wastes [11]. Bad management of uranium mine and mills tail

Table 1. Activities that may lead to NORM contaminated residues and sites [2].

\begin{tabular}{|c|c|c|}
\hline $\begin{array}{l}\text { Mineral ores } \\
\text { and extracted } \\
\text { materials }\end{array}$ & & $\begin{array}{l}\text { Other processing/ } \\
\text { manufacturing }\end{array}$ \\
\hline Copper & Titanium & Water treatment \\
\hline $\begin{array}{l}\text { Aluminum } \\
\text { (bauxite) }\end{array}$ & Tungsten & Sewage treatment \\
\hline Fluorspar & Vanadium & Spas \\
\hline Gypsum & Zircon & Paper and pulp \\
\hline Iorn & $\begin{array}{l}\text { Coal (and } \\
\text { coal ash) }\end{array}$ & Ceramics manufacture \\
\hline Molybdenum & Oil and gas & $\begin{array}{l}\text { Paint and pigment } \\
\text { manufacture }\end{array}$ \\
\hline Phosphate & $\begin{array}{c}\text { Geothermal } \\
\text { energy }\end{array}$ & Metal foundry \\
\hline Phosphorous & Thorium & Optics \\
\hline Potassium & & Incandescent gas mantles \\
\hline Rare earth & & $\begin{array}{l}\text { Refractory and } \\
\text { abrasive sands }\end{array}$ \\
\hline Uranium & & Electronics manufactures \\
\hline Tin & & Building materials \\
\hline
\end{tabular}

ings can cause soil and groundwater pollution, to address this issue, regulatory bodies in different countries have issued national regulations. In 2011, UK have published guidelines from management of NORM in this guide, indus trial activities that generate NORM were classified into two categories; activities that employ uranium or thorium and activities in which NROM presence is incidental. The concen tration limit to include NORM as radioactive material was identified for different radionuclides, for example, if ${ }^{226} \mathrm{Ra}$ exceed $0.5 \mathrm{bq} / \mathrm{g}$ in solid or relevant liquid for first category, NORM will be treated as radioactive wastes [12].

In Canada, NORM management is not regulated by the Canadian nuclear safety commission, but it fall under juris diction of the provinces and territories. To eliminate cross jurisdictional boundaries among radiation protection stand ards, new guidelines were developed in 2000. In these guidelines, industries that generate NORM in significant amount to yield in radiation doses require the application of radiation protection practice were identified to include min eral extraction and processing: oil and gas production, metal recycling: forest products and thermal electric production, water treatment facilities: and tunneling and underground workings [13]. The guideline recommended the release NORM from regulatory requirements if the associated dose was found less than $0.3 \mathrm{mSv} / \mathrm{y}$

In USA, NRC issued regulations to reduce emanations of radon from tailings, prevent the spreading of tailings through erosion, reduce contamination by seepage, and setting out requirements to perform risk assessment [14]. The regulation specified the utilization of passive disposal with a minimum life time of 200 year, the average maximum permissible radon concentration was recommended to be less than 5 pci/g. The goals of the remediation activities were indicated within the regulation to achieve radon decay product con centration less than 0.03 working level and gamma radiation level not exceeding $20 \mu \mathrm{R} / \mathrm{h}$ above background.

The Spanish limiting criteria for releasing NORM contaminated land are utilizing the following dose rate limit; doses should not exceed $300 \mu \mathrm{Sv} / \mathrm{yr}$ (excluding radon doses), ${ }^{222} \mathrm{Rn}$ concentrations in hypothetical future dwellings should not exceed $200 \mathrm{~Bq} / \mathrm{m}^{3}$; and finally ALARA (as low as reasonable achievable) principals should be applied [15]. Michalik et al. concluded that irrespective of the final form of further European regulation, the evolution of the approach to protect the environment against ionizing radia tion will force the radiological protection community to face the problem of how to quantify, in a convincing manner, the environmental impacts when an assessment is needed [16]. When there is no severe environmental impact it is enough for the provision of scientifically well justified evidence that the actual presence of radioactivity does not cause any effect on the environment.

Table 2. IAEA radiological criteria to support remediation decision making [5, 6].

\begin{tabular}{|c|c|c|c|}
\hline Band & $\begin{array}{l}\text { Need for remediation } \\
\text { actions }\end{array}$ & Acceptability of release & $\begin{array}{c}\text { Range of } \\
\text { annual doses }\end{array}$ \\
\hline 6 & Remediation or prevent use & Not suitable for release, & $>100 \mathrm{mSv} / \mathrm{a}$ \\
\hline 5 & Remediation or restrict use & Not suitable for release, & $10100 \mathrm{mSv} / \mathrm{a}$ \\
\hline 4 & $\begin{array}{l}\text { Remediation decisions based } \\
\text { on justification/ optimization }\end{array}$ & $\begin{array}{l}\text { May be released, but subject to } \\
\text { regular review of situation }\end{array}$ & $110 \mathrm{mSv} / \mathrm{a}$ \\
\hline 3 & $\begin{array}{l}\text { Remediation unlikely unless } \\
\text { constrained }\end{array}$ & Released, but may need occasional review & $0.11 \mathrm{mSv} / \mathrm{a}$ \\
\hline 2 & $\begin{array}{l}\text { Remediation unlikely to be necessary } \\
\text { on the basis of radiological risks }\end{array}$ & $\begin{array}{l}\text { Likely released, review is needed } \\
\text { only if a problem becomes apparent }\end{array}$ & $10100 \mu \mathrm{Sv} / \mathrm{a}$ \\
\hline 1 & No remediation necessary & Can be released without controls & $<10 \mu \mathrm{Sv} / \mathrm{a}$ \\
\hline
\end{tabular}


Table 3. IAEA remediation technology evaluation matrix [5, 6].

\begin{tabular}{|c|c|c|c|}
\hline Evaluation factor & Exemplary & Acceptable & Unacceptable \\
\hline Performance & Near $100 \%$ removal & $\begin{array}{l}\text { Removes contaminants to } \\
\text { desired limit }\end{array}$ & $\begin{array}{l}\text { Mobilized or additional } \\
\text { contaminant }\end{array}$ \\
\hline Reliability & Near $100 \%$ reliable & $\begin{array}{l}\text { Available without excessive } \\
\text { down time }\end{array}$ & Unreliable \\
\hline Maintenance & Minimal & Occasional & $\begin{array}{l}\text { Unavailable suppliers or at } \\
\text { great cost }\end{array}$ \\
\hline Cost & $\begin{array}{l}\text { Costs recoverable against } \\
\text { credits }\end{array}$ & Cost within acceptable levels & Excessive cost \\
\hline $\begin{array}{l}\text { Infrastructure support } \\
\text { technology }\end{array}$ & $\begin{array}{l}\text { Not needed or fully available } \\
\text { and already in place }\end{array}$ & Available & $\begin{array}{l}\text { Unavailable or requires } \\
\text { significant expense to provide }\end{array}$ \\
\hline Availability & Well proven & $\begin{array}{l}\text { Demonstrated and available in } \\
\text { short time frame }\end{array}$ & $\begin{array}{l}\text { Unproven/early in } \\
\text { development }\end{array}$ \\
\hline Risk & No risk to public or operators & $\begin{array}{l}\text { Risk to public or operators } \\
\text { within regulatory guidelines }\end{array}$ & $\begin{array}{l}\text { More risk than if nothing } \\
\text { done }\end{array}$ \\
\hline Impact on environment & Clean and green & $\begin{array}{l}\text { Little effect on overall } \\
\text { ecosystem }\end{array}$ & Significant pollution/ damage \\
\hline Regulatory acceptance & Exceeds regulatory standards & Meets regulatory standards & Fails regulatory standards \\
\hline Community acceptance & $\begin{array}{l}\text { Wholehearted acceptance } \\
\text { without reservation }\end{array}$ & $\begin{array}{l}\text { Acceptance with two way } \\
\text { dialogue }\end{array}$ & Unacceptable \\
\hline
\end{tabular}

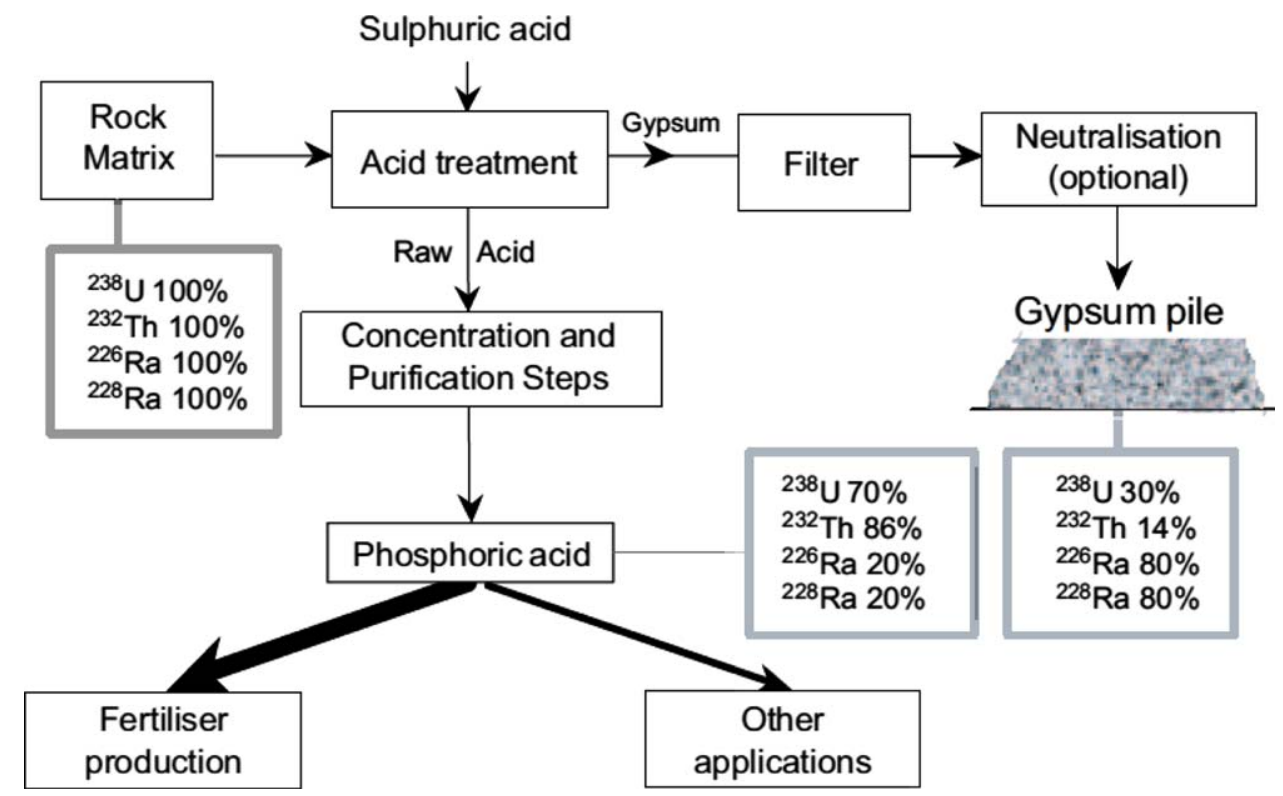

Figure 1. Radiocontaminant flow through phosphoric acid production [2]. [Color figure can be viewed in the online issue, which is available at wileyonlinelibrary.com.]

Recently the Korean government had started to establish a regulatory framework for natural radiation including NORM/TENORM. The main motivation was the rapid eco nomic growth in Korea that consume huge amount of raw materials, including NORM and TENORM [17].

\section{RECENT ADVANCES IN RADIOLOGICAL ASSESSMENT OF TENORM}

\section{TENORM from Fertilizers Industry}

To comply with radiation protection and environmental regulation there is a need to perform accurate and reliable assessment of the contamination and/or pollution extent. Fertilizers industry produces phosphogypsum, which is the principal TENORM waste product, the radio contaminant flow through the phosphoric acid production using wet sulphoric acid method is illustrated in Figure 1 [2].
Recently, the interest in evaluating the extent of NORM and TENORM in these industrial wastes and its radiological impact on human and the environment have been contin ued. This section is devoted to review these researches methodology and their most important findings. A new phosphogypsum reference material was produced and cer tified to assist in the validation of analytical methods and quality assurance of generated analytical results [18]. Sam ple preparation methodology, material homogeneity assess ment, characterization campaign results and assignment of property values, and associated uncertainties were deter mined. The reference values and associated uncertainties for ${ }^{210} \mathrm{~Pb},{ }^{226} \mathrm{Ra},{ }^{230} \mathrm{Th},{ }^{234} \mathrm{U}$ and ${ }^{238} \mathrm{U}$ were established based on consensus values calculated from analytical results reported by three National Metrology Institutes and five expert laboratories. 
To evaluate the radiological impact of a phosphoric acid factory located in the south western Spain, the distribution and levels of radionuclides in the materials involved in the production process have been analyzed. The flow of radio nuclides at each step was assessed and locations of possible radionuclide accumulation were identified. A set of samples collected along the whole production process were analyzed to determine their radionuclide content by both alpha particle and gamma spectrometry techniques. The radionu clide fractionation steps and enrichment sources have been located, allowing the establishment of their mass (activity) balances per year [19].

The radiological characterizations of disposed phospho gypsum were determined, the outdoor storage and transport radiological impacts and phosphogypsum usage as additive and filling materials in construction sectors were studied [20]. It was found that the mean activity concentrations of ${ }^{226} \mathrm{Ra}$, ${ }^{232} \mathrm{Th}$ and ${ }^{40} \mathrm{~K}$ measured for the studied samples were in the range $436.0125 .0,15.19 .4$ and $13.07 .5 \mathrm{~Bq} / \mathrm{kg}$ respectively. These values were concluded to fall below recommended safety limits for usability of phosphogypsum as aggregate in roads constructions sector in Turkey. Generic exposure sce nario was used to evaluate the radiological impact on public members and workers, the results indicated that the eval uated mean annual effective doses were lower than the annual limit of $1 \mathrm{mSv} / \mathrm{y}$.

The chemical and radiochemical composition of a solid waste generated in phosphoric acid production plant were determined using analytical methods [21]. The analysis and leaching of samples containing ${ }^{210} \mathrm{~Pb}$, and ${ }^{210} \mathrm{Po}$ mixed with high activity concentration of uranium isotopes using gamma spectrometry and radiochemical methods showed a very low quantity of ${ }^{226} \mathrm{Ra}$. To evaluate the leachability of $\mathrm{U}$ isotopes, ${ }^{210} \mathrm{~Pb}$ and ${ }^{210} \mathrm{Po}$, sequential extraction method consisting of five operational defined fractions was used. The results indi cated that the average leaching potential was $97.6 \%$ for ${ }^{238} \mathrm{U}$, $93.2 \%$ for ${ }^{210} \mathrm{~Pb}$ and $82.4 \%$ for ${ }^{210} \mathrm{Po}$. Moreover the study showed that ${ }^{210} \mathrm{~Pb}$ and ${ }^{210} \mathrm{Po}$ are leachable under extreme conditions, where $\mathrm{U}$ isotopes are more soluble.

During a preliminary survey at the area of an abandoned fertilizer plant, increased levels of radioactivity were meas ured at places, buildings, constructions and materials. The extent of the contamination was determined and the affected areas were characterized as controlled areas. After quantita tive and qualitative determination of the contaminated mate rials, decontamination program was planned and performed step by step: the contaminated materials were categorized according to their physical characteristics (scrap metals, plas tic pipes, scales and residues, building materials, etc) and according to their level of radioactivity. Depending on the material type, different decontamination and disposal options were proposed; the most appropriate technique was chosen based on technical factors, legal requirements, radiation pro tection standards, the opinion of stakeholders. After remov ing the biggest amount of the contaminated materials, an iterative process consisting of surveys and decontamination actions were performed in order to remove the residual traces of contamination from the area. During the final sur vey, no residual surface contamination was detected; some sparsely distributed low level contaminated materials deeply immersed into the soil were found and removed [22].

\section{TENORM from Water Treatment}

In southeast Queensland, Australia, an assessment of TENORM generation during the treatment of water supplies was performed. Radioactivity concentrations of ${ }^{238} \mathrm{U},{ }^{232} \mathrm{Th}$, ${ }^{226} \mathrm{Ra},{ }^{222} \mathrm{Rn}$, and ${ }^{210} \mathrm{Po}$ in surface water and groundwater samples were examined both pre and post treatment. The treatment of processes applied to surface water included such as sedimentation, flocculation, coagulation, and filtra tion while cation exchange, reverse osmosis, and activated charcoals are used to treat groundwater. The secondary waste generated after treatment were identified to include sludges, exhausted ion exchangers, filtration media, back wash and wastewaters and their activity concentration were measured. The measured activity concentrations were used as input parameters to model the radiological impact of the secondary wastes. The results indicated that the water treat ment practice in Australia does not pose a significant radio logical risk [23].

\section{TENORM from Oil and Gas Industry}

Oil and gas industries represent the main source for TEN ORM, the flow of radiocontaminants in different parts of the oil and gas production site and refining plants is illustrated in Figure 2 [2]. The distribution of radon gas and radiation exposure rates were evaluated in four natural gas treatment facilities in Syria [24]. The radiation exposure rates at the equipment area were found within the natural levels (0.09 $0.1 \mu \mathrm{Sv} / \mathrm{h}$ ) except for the reflex pumps where a dose rate value of $3 \mu \mathrm{Sv} / \mathrm{h}$ was recorded. The concentrations of Radon in Syrian natural gas are in the range $15.41141 \mathrm{~Bq} / \mathrm{m}^{3}$; the concentration is higher in the associated natural gas than that of the non associated gas. The concentrating and pressuriz ing processes in the central processing facilities were found to be responsible for the detected high radon concentration. The lowest detected ${ }^{222} \mathrm{Rn}$ concentration was found in the natural gas fraction equals $80 \mathrm{~Bq} / \mathrm{m}^{3}$. On the other hand, maximum observed radon gas and its decay product concen trations were found to be high in the gas analysis laborato ries (equal $458 \mathrm{~Bq} / \mathrm{m}^{3}$ ). However, the reported levels in the studied stations were below the $1000 \mathrm{~Bq} / \mathrm{m}^{3}$ limit set by IAEA for radon chronic exposure [24].

Karen et al. highlighted the interest of both industry and regulators in identifying cost effective disposal alternatives that provide adequate protection of human health and the environment. One such alternative, currently allowed in Michigan with restrictions, is the disposal of TENORM wastes in nonhazardous waste landfills. The disposal of petroleum industry wastes containing ${ }^{226} \mathrm{Ra}$ in nonhazardous landfills was modeled to evaluate the potential radiological doses and health risks to workers and the public. Multiple scenarios were considered in evaluating the potential risks associated with landfill operations and the future use of the property. The scenarios were defined to evaluate Michigan policy; sen sitivity analyses were conducted to evaluate the impact of key parameters on potential risks. The results indicated that the disposal of petroleum TENORM wastes in nonhazardous landfills in accordance with Michigan policy and existing landfill regulations presents a negligible risk to most of the considered potential receptors [25].

The characterization of TENORM from the oil and gas industry in Egypt were overviewed, the average activity con centrations of ${ }^{226} \mathrm{Ra}$ in scale and sludge samples were found to change between 5.9 and $68.9 \mathrm{kBq} / \mathrm{kg}$ (dry weight) in the waste samples from Gabal El Zeit field and Abu Rudeis fields, respectively. The mean activity concentrations of ${ }^{232} \mathrm{Th}$ were $25.4,2.6$, and $7.2 \mathrm{kBq} / \mathrm{kg}$ and those of ${ }^{40} \mathrm{~K}$ were 1.3 , 0.96 , and $2.3 \mathrm{kBq} / \mathrm{kg}$, for Abu Rudeis, granular Gabal El Zeit, and massive Gabal El Zeit [26].

\section{TENORM from Uranium Mining}

As a benchmark for the old uranium mining sites reme diation, the radiological health risk on the basis of dose assessment for naturally occurring uranium geochemical anomalies as a representative of Iberian Massif (Portuguese section) was conducted. Uranium, thorium and potassium radioactive series were measured in 52 samples taken from 


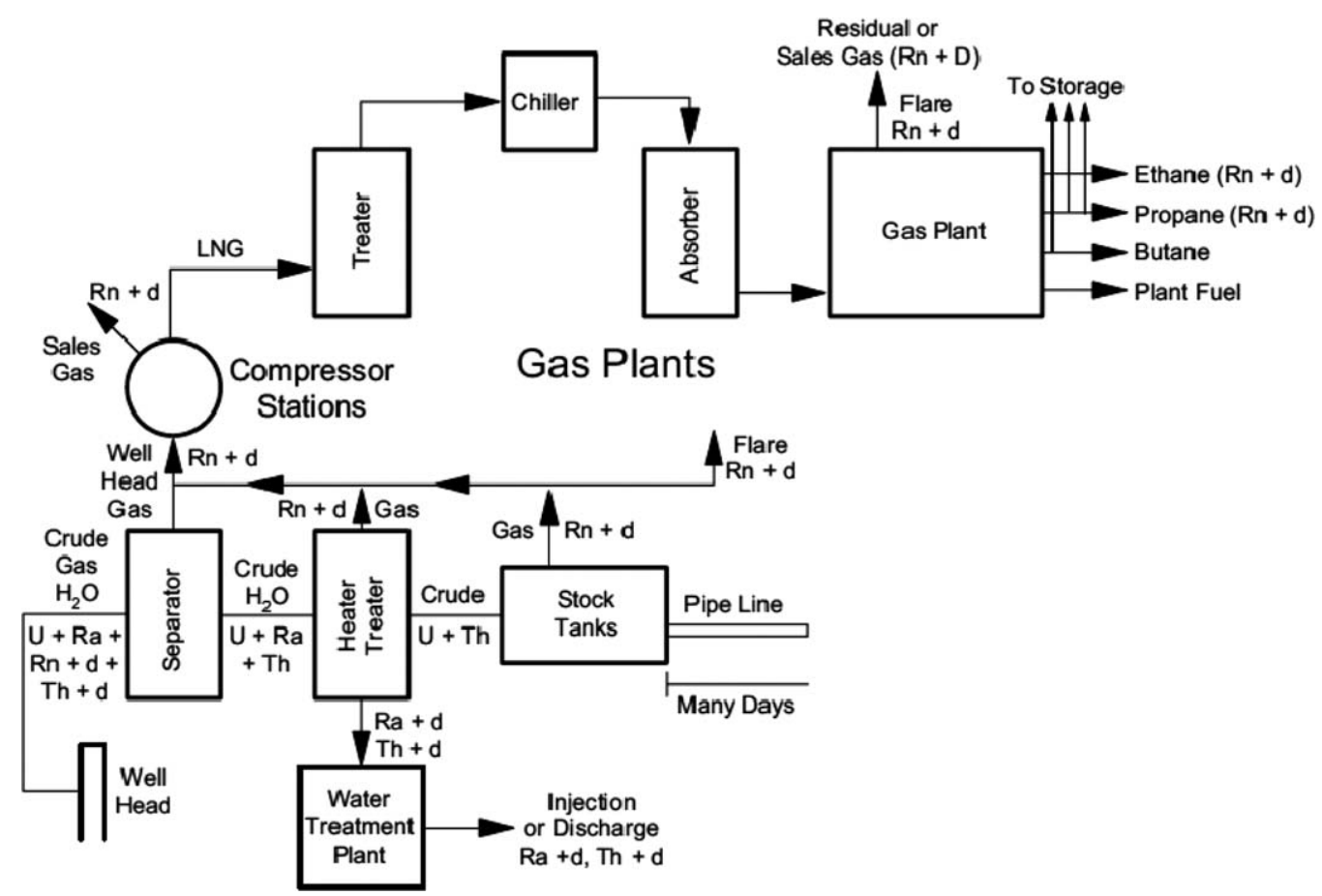

Figure 2. Radiocontaminants flow through gas and oil industry [2].

different environmental compartments: soils, stream sedi ments, water, foodstuff (vegetables) and air; external radiation was also measured through a square grid of $10 \times 10 \mathrm{~m}$, with a total of 336 measurements. The results showed that some radioisotopes have high activities in all the environmental compartments as well as a large variability, namely for those of the uranium decay chain, which is a common situation in the regional geological setting. Isotopic disequilibrium is also common and led to an enrichment of several isotopes in the different pathways, as is the case of ${ }^{226} \mathrm{Ra}$; maximum values of $1.76 \mathrm{~Bq} / \mathrm{L}$ (water), $986 \mathrm{~Bq} / \mathrm{kg}$ (soils), and $18.9 \mathrm{~Bq} / \mathrm{kg}$ (in a turnip sample) were measured. On the basis of a realistic sce nario combined with the experimental data, the effective dose from exposure to ionizing radiation for two groups of popula tion (rural and urban) was calculated; the effective dose is variable between 8.0 and $9.5 \mathrm{mSv} / \mathrm{y}$, which is 34 times higher than the world average [27].

Monitoring in situ leaching uranium mine groundwater, based on the monitoring of groundwater quality and the bot tom value of groundwater pollution control was recently studied [28]. It was found that the operation of acid leaching mining area can led to groundwater contamination with sul fate and nitrate. The determination of the current range of contaminant concentration is considered the basic data for the groundwater remediation.

\section{REMEDIATION TECHNOLOGY}

A wide range of remediation technologies is available to deal with contaminated sites, this section will highlight recent remediation researches applicable for remediating sites contaminated with NORM and TENORM such as passive barriers, pump and treat, electokinetic, and bioremediation.

\section{Barrier Technology}

Permeable reactive barrier (PRB) is a class of passive engineering barriers that is installed to remediate contami nated groundwater. The basic idea of this technology is to place suitable material that has chemical reactivity toward one or more contaminant in the contaminated groundwater path. As groundwater passes through the barrier, contami nants are removed by adsorption, exchange, oxidation reduction, or precipitation mechanisms of the barrier material [10]. Precipitation of phosphate minerals is one of the tech nological options used to remediate groundwater contami nated with uranium. The thermodynamic calculations for potassium and calcium uranyl phopsphates, meta ankoleite and autunite showed that uranium concentrations will exceed the maximum contaminant level $(0.13 \mu \mathrm{M}$ for $\mathrm{U})$ at any $\mathrm{pH}$, unless phosphate concentrations is maintained higher than the sub $\mu \mathrm{M}$ levels typically found in groundwater [29]. Tokunaga et al. indicated that potassium uranyl vana date can control uranium concentrations below regulatory limits in slightly acidic to neutral solutions. The calculations showed that maintaining uranium concentrations below the maximum contaminant level could be achieved by precipitat ing carnotite $\left(\mathrm{K}_{2}\left(\mathrm{UO}_{2}\right)_{2} \mathrm{~V}_{2} \mathrm{O}_{8}\right.$. $)$ in oxidizing waters $(\mathrm{pH}$ 5.5 7) [29]. Experimental results for solutions at $\mathrm{pH} 6.0$ and 7.8 were used to identify the optimum conditions to drop uranium concentration below MCL to provide contact within 15 days with oxidizing solutions containing $0.210 \mathrm{mM} \mathrm{K}$, and $0.120 \mu \mathrm{M} \mathrm{V}(\mathrm{V})$.

Column experiments on remediation of acid seepage water from uranium containing debris using slated lime and silica sand mixture as permeable reactive barrier have been conducted [30]. The results showed that the studied mixture gave good results; i.e., the utilization of one unit volume of the mixture can neutralize $108.3,53.5$, and 45.9 unit volume of acid seepage water $(\mathrm{pH} 3.12)$ with 1:5, 1:7, and 1:9 slated lime to sand mass ratio. That work indicated that for contam ination less than $0.05 \mathrm{mg} / \mathrm{L}$ uranium concentration in filtrate at $\mathrm{pH}<6.5$, the performance of uranium removal is good and fade removal performance for sulfate radical. The per meability of the mixture with 1:5 mass ratio was decreased from $10.9 \mathrm{~m} / \mathrm{d}$ to $6.1 \mathrm{~m} / \mathrm{d}$, but the other two had no obvi ously change.

In Romania, there were three uranium mining areas, Banat region in southwest Romania, Apuseni Mountains in 
the west, and Crucea in the north. The operation of these mines has led to pollution problems. The application of nanoparticles zero valent iron (nano $\mathrm{Fe} 0$ ) and nanoparticles magnetite (nano $\mathrm{Fe}_{3} \mathrm{O}_{4}$ ) for uranium removal from carbonate rich water taken from Lişava valley, Banat, Roma nia was performed. Nanoparticles were introduced to Lişava groundwater with a uranium VI. Liquid and nanoparticulate samples were collected and analyzed periodically over 84 days [31]. That study indicated that uranium 98\% removal was achieved by nano $\mathrm{Fe} 0$ systems within $2 \mathrm{~h}$ of reaction, which reduce uranium concentration below EPA and WHO specified drinking water regulations. The results of $\mathrm{X}$ ray photoelectron spectroscopy analysis of the nanoparticulate solids confirmed the partial chemical reduction of uranium VI to Uranium IV, which is the most stable form. This result was attributed to the presence of $\mathrm{Fe} 0$ core that achieve near total removal of aqueous uranium even with the presence of competing ions. Over extended reaction periods (nearly 1 week) uranium VI was completely removed using nano Fe0.

Experimental studies using mine waters from Banat Romania area, in discontinuous single contact of phases was performed to select optimal reactive materials based on the distribution coefficient [32]. The results concluded the distri bution coefficient of activated carbon type AC20G is the highest followed by that of apatite, while natural zeolites and zero valent iron had the lowest distribution coefficients. The fixed bed studies of these materials indicated that for an ini tial uranium concentration of $1.72 \mathrm{mg} / \mathrm{L}$, the water could be decontaminated to less than $0.048 \mathrm{mg} / \mathrm{L}$ after $120 \mathrm{~h}$.

Acid mine water from Straz pod Ralskem, Czech Republic, was remediated in by nanoparticles zero valent iron (nano $\mathrm{Fe} 0$ ). Toxicity of the remediated water was attributed to the presence of aluminum and sulphates in a high concentration, and the micro contaminants e.g. As, $\mathrm{Cd}, \mathrm{Cr}, \mathrm{U}, \mathrm{V}$, and $\mathrm{Zn}$. Batch results showed significant decrease in pollutant con centrations due to $\mathrm{pH}$ enhancement and the decrease in oxidation reduction potential related to an application of nano Fe0. The contaminants were concluded to be removed be different mechanisms including cations precipitation in lower oxidation state, precipitation due to $\mathrm{pH}$ enhancement and coprecipitation with the formed iron oxyhydroxides [33].

Permeable reactive barriers for remediating acid mine drainage with low level uranium was studied [34]. In that work, 721 mine located in Jiangxi province were considered. The results showed that this remediation technique reduced uranium concentration to meet radioactive wastewater dis charged standard, and acidity meets guide standard [34].

\section{Pump and Treat Technology}

Pump and treat technology is one of the commonly used techniques for groundwater remediation. The development of unconfined groundwater flow and transport model using mesh free point collection method was presented by Mate gaonkar et al. [35]. The developed models are coupled to get an effective simulation/optimization model for the ground water remediation design using pump and treat technology. The simulation/optimization model was applied to the reme diation design of an unconfined field aquifer polluted by Total Dissolved Solids (TDS) using pump and treat and flushing. The model provides an effective remediation design of pump ing rate for the selected wells and costs of remediation [35].

Remediation of the Site Brook waterway was based on the need to remove contaminated floodplain soil and sedi ments while limiting the impacts on the surrounding ecologi cal environment. The Site Brook remediation included soil and/or sediment excavation from wetlands, the wetland buffer zone, and upland areas. During the planning phase, characterization data were plotted and evaluated from histor ical surveys. In addition to the in stream surveys, workers collected sediment samples using a hand auger from each grid where an elevated count rate greater than background was identified. For excavation of areas within the stream channel, a surface water diversion system was installed to convey stream flow around the excavation area and elimi nate the flow of surface water through the excavation. A sump installed in the excavation area collected groundwater recharge into the excavation area and pumped it into a hold ing tank for radiological sampling and analysis prior to treat ment via filtration and discharge to the Publicly Owned Treatment Works [36].

\section{Electrokinetic Remediation}

Electokinetic remediation is a relatively new physicochemi cal method used to mobilize ionic pollutants for removal in subsurface. Soil contaminated with organic and heavy metal pollutants could be remediated using this technology. The major drawback of this technology is the precipitation of reduced contaminants around the electrodes which implies the utilization of washing systems or adding augmenting fluids to prevent precipitates formation. The utilization of integrated bioelectrochemical system was proposed to overcome these drawbacks [37]. A microbial fuel cell was selected for studying the remediation of heavy metals such as uranium and chro mium. The main factors that affect the performance of this technology were characterized. The results showed that the removal of hexavalent chromium is highly dependent on soil condition and the initial concentration.

To overcome the precipitation of reduced contaminants, improvements were carried out on the pilot scale electroki netic equipment in Korean nuclear facility sites. These improvements include; immersion washing device, metal oxide separator, and circulation system. The aim from using the immersion washing device is cleaning the metal oxides from the cathode plate. The separator is used to remove the oxide particles below $0.075 \mathrm{~mm}$. Finally, the circulation sys tem is used to control $\mathrm{pH}$ and ensure waste solution move ment. The $\mathrm{pH}$ in the cathode room is adjusted at 12 , to prevent the generation of metal hydroxide and circulates waste solution to prevent the increase of metal oxides due to its stagnancy. After the remediation experiment for 25 days using improved pilot scale electrokinetic equipment, the removal efficiency of uranium from the soil was $96.8 \%$, and its residual uranium concentration was $0.81 \mathrm{~Bq} / \mathrm{g}$. When the initial uranium concentration of the soil was $50 \mathrm{~Bq} / \mathrm{g}$, the electrokinetic remediation time required to remediate the uranium concentration below clearance concentration of 1.0 Bq/g was about 34 days. When the initial uranium con centration of soil was $75 \mathrm{~Bq} / \mathrm{g}$, the electrokinetic remediation time required to remediate below $1.0 \mathrm{~Bq} / \mathrm{g}$ was about 42 days. When the initial uranium concentration of soil was $100 \mathrm{~Bq} / \mathrm{g}$, the electrokinetic remediation time required to remediate below $1.0 \mathrm{~Bq} / \mathrm{g}$ was 49 days [38].

The treatment uranium leachate generated from the elec trokinetic remediation was studied by using mixing and cohesion, precipitation, concentration, and filtration [39]. The leachate characteristics were performed and the results indi cated that U concentration was $180 \mathrm{ppm}$. By using sodium hydroxide as a precipitant it was found that, the precipitation velocity was reduced and the precipitate particle size was increased. In several respects, sodium hydroxide was found to be more efficient as a precipitant than ammonium and cal cium hydroxides. The results showed that a mixture of $\mathrm{NaOH}$, alum, and magnetite (having weight ratio of 20:4:3) is optimal for filtration [39].

\section{Biological Treatments}

Natural uranium and ${ }^{226} \mathrm{Ra}$ removal from contaminated waters by rhizofiltration was tested using Helianthus annuus 
L. (sunflower) seedlings growing in a hydroponic medium [40]. The optimum age of the seedlings was studied and radionuclides removals using sunflower roots were tested. The results revealed that the seedlings induced the formation of precipitate that contains $\mathrm{U}$ and $\mathrm{Ra}$. Contaminated water was remediated successfully using four week old seedlings for 2 days. $50 \%$ of the $\mathrm{U}$ and $70 \%$ of Ra were fixed in the roots, and the rest were detected in the precipitate [40].

Optimum conditions for penatron and soil mixing, and the soil $\mathrm{pH}$ of were studied using different bioremediations with soil contaminated by $\mathrm{U}$ and $\mathrm{Ra}$. It was found that an optimum mixing ratio of penatron for bioremediation of ura nium soil was $1 \%$. Also, the optimum $\mathrm{pH}$ condition for biore mediation of soil contaminated with $\mathrm{U}$ and $\mathrm{Ra}$ was 7.5. Removal efficiencies from higher concentration of contami nated soil were reduced in comparison with those from lower concentration of soil. Meanwhile, the removal of ura nium and radium in concrete by bioremediation is possible but the removal rate from concrete was slower than that from soil. The removal efficiencies of uranium and radium from soil under injection of $1 \%$ penatron at $\mathrm{pH} 7.5$ for 120 days were 81.2 and $81.6 \%$, respectively, and the removal effi ciencies of uranium and radium from concrete under the same condition were 63.0 and $45.2 \%$, respectively. Beyond 30 days, removal rates of uranium and radium from soil and concrete by bioremediation was very slow [41].

Uranyl ions biosorption on three types of alga: Nostok linckia, Porphyridium cruentum, and Spirulina platensis was studied. These ions were supplied either from a pure solu tion of uranyl nitrate, or after uranium ore leaching, or from the purification sludge. The retention degree versus contact time and afterwards the Langmuir and Freundlich biosorp tion isotherms of uranyl ions on the three alga types were investigated. The retention of contaminants ions on alga was proved through FTIR investigations. From the experimental data it was found that regardless of origin of uranyl ions, the retention degree on alga decreased in the series. Spirulina platensis t; Porphyridiumcruentum $\geq$ Nostoklinckia [42].

Geobacter mediated reductive immobilization of uranium is a novel bioremediation technique. While several reactive transport models have been developed to represent Geobacter mediated bioremediation of uranium, these mod els often lack the detailed quantitative description of the microbial process (e.g., biomass buildup in both ground water and sediments, electron transport system, etc.) and the interaction between biogeochemical and hydrological pro cess. A recent study devoted to the development of a novel multi scale model by integrating a recent model on electron capacitance of Geobacter with a comprehensive simulator of coupled fluid flow, hydrologic transport, heat transfer, and biogeochemical reactions. This mechanistic reactive transport model accurately reproduces the experimental data for the bioremediation of uranium with acetate amendment. The proposed model captured significant contributing factors across time and space, thereby improving the structure and parameterization of the comprehensive reactive transport model. The global sensitivity analysis also provides a poten tially useful tool to evaluate uranium bioremediation strategy. The simulations suggest that under difficult environments (e.g., highly contaminated with U(VI) at a high migration rate of solutes), the efficiency of uranium removal can be improved by adding Geobacter species to the contaminated site (bioaugmentation) in conjunction with the addition of electron donor (biostimulation). The simulations also high light the interactive effect of initial cell concentration and flow rate on $\mathrm{U}(\mathrm{VI})$ reduction [43].

The utilization of phytoextraction for remediating soils contaminated with uranium has received increasing attention recently. The remediation of $10 \mathrm{~cm}$ soil depth having 1.5 $\mathrm{kg} \mathrm{dm}{ }^{3}$ density contaminated with $\mathrm{Cs}$, Sr, and $\mathrm{U}$ by using phytoextraction was studied. The annual removal percent for these contaminants were found $3.3,5$, and $9.3 \%$, respectively which entailed the application of this method for 23,10 , and 7 years for each contaminant for the removal of $50 \%$ without the consideration of decay $[44,45]$. The feasibility of using cit ric acid, oxalic acid, nitrilotriacetic acid, and EDTA for phy toremediation of uranium tailings by Indian mustard was tested [46]. The tailings were mixed with garden soils at 1:3 ratio and four different chelators concentrations were added to the mixture. EDTA was found to produce maximum growth depression where nitrilotriacetic acid gives the mini mum. The minimum growth inhabitation observed was with nitrilotriacetic acid which was followed by oxalic acid, citric acid and finally EDTA. Another study devoted to investigate the effect of citrate, EDTA, and EDDS on the removal of radium from a granitic soil [47]. The removal process for all the studied chelators were found dependent on the substrate $\mathrm{pH}$. The highest radium removal was obtained for citrate amendment at $50 \mathrm{mmol} / \mathrm{kg}$ and the maximum removal was attained on the first day after amendment while using citrate will lead to delay till the fourth Day.

\section{CONCLUSIONS}

This work aimed to highlight the scientific community interest in important topics that affect the selection of reme diation technology. From this review the following conclu sions could be drawn

1. Different materials have been tested for their potential use as reactive barriers to remediate uranium from conta minated groundwater, these include Potassium Uranyl Vanadate, slated lime and silica sand mixture, iron zero valent, magnetite, activated carbon, apatite, natural zeolites.

2. zero valent iron has received a great attention recently, but there is still a need to investigate how to improve the retention of inorganic contaminants in chemically com plex environmental

3. Laboratory scale researches have been extensively per formed but the pilot scale results were not adequately presented. So there is a need to study and/or model the effect of upscaling on the obtained experimental results.

4. Large uncertainties associated the fundamental process that governs bioreactor operation, i.e. transport and bio catalysis mechanisms, these uncertainties need to be addressed.

\section{LITERATURE CITED}

1. International Atomic Energy Agency, General Environ mental Impact Assessment Methodology Approach (Model Development Process) for NORM Sites Working Group;, Reference approach for risk and environmental impact assessments necessary for management and reme diation of NORM and legacy sites EMRAS II Norm and Legacy Working Group, www ns.iaea.org/downloads/ .../draft gen ass meth proc.pdf

2. International Atomic Energy Agency. Extent of environ mental contamination by naturally occurring radioactive material (norm) and technological options for mitigation; TRS 419; IAEA: Vienna, Austria, 2003.

3. Abdel Rahman, R. O. Planning and Implementation of Radioactive Waste Management System, In Radioactive, Waste; R. O. Abdel, Rahman, (Ed.); InTech: Rijeka, Croatia, 2012; pp. 3 18. http://www.intechopen.com/books/ radioactive waste/planning and implementation of radioactive waste management system

4. Chapman Peter, M. (2007). Determining when contamina tion is pollution Weight of evidence determinations for 
sediments and effluents, Environment International 33, 492501.

5. International Atomic Energy Agency. Technologies for remediation of radioactively contaminated sites; IAEA TECDOC 1086; IAEA, Vienna, Austria, 1999.

6. International Atomic Energy Agency. Application of radia tion protection principles to the cleanup of contaminated areas; IAEA TECDOC 987; IAEA, Vienna, Austria, 1997.

7. Morrison Stan, J., Naftz David, L., Davis James, A., \& Fuller Christopher, C. (2002). Introduction to ground water remediation of metals, radionuclides, and nutrients with permeable reactive barriers, In Handbook of Groundwater Remediation Using Permeable Reactive Bar riers, L.N., David, S.J., Morrison, C.C., Fuller, \& J.A., Davis (Eds.); Elsevier,; pp 115.

8. Abdel Rahman, R.O., Abdel Moamen, O.A., Hanafy, M., \& Abdel Monem, N.M. (2012). Preliminary investigation of zinc transport through zeolite $\mathrm{X}$ barrier: Linear iso therm assumption, Chemical Engineering Journal, 185 186, 6170 .

9. Ellis David, E., \& Hadley Paul, W. (2009). Sustainable remediation white paper Integrating sustainable princi ples, practices, and metrics into remediation, Projects, Remediation 19, 5114.

10. Interstate Technology \& Regulatory Council. Green and sustainable remediation: A practical framework. GSR 2. ITRC, Washington, D.C., UAS, 2011.

11. International Atomic Energy Agency. Regulatory and management approaches for the control of environmental residues containing naturally occurring radioactive mate rial (NORM); IAEA TECDOC 1484; IAEA, Vienna, Austria, 2006.

12. Guidance on the scope of and exemptions from the radi oactive substances legislation in the UK, 2011, www. defra.gov.uk (accessed on 13 2013).

13. Canadian Guidelines for the Management of Naturally Occurring Radioactive Materials (NORM), Canadian NORM Working Group of the Federal Provincial Territo rial Radiation Protection Committee, 2000. Available at: http://www.lrws.gov.sk.ca/adx/aspx/adxGetMedia.

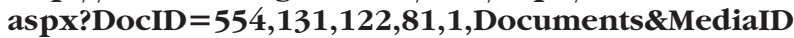
$=\mathbf{3 0 7 \& F i l e n a m e}=$ norm.pdf $($ last accessed 1303 2013)

14. 40 CFR 192.32 standards, http://www.law.cornell.edu/ cfr/text/40/192.32 (last accessed 1303 2013).

15. Gavrilescu, M., Vasile Pavel, L., \& Cretescu, I. (2009). Characterization and remediation of soils contaminated with uranium, Journal of Hazardous Materials, 136(2 3), 475510.

16. Michalik, B., Brown, J., \& Krajewski, P. (2013). The fate and behaviour of enhanced natural radioactivity with respect to environmental protection, Environ. Impact Assess., 38, 163171.

17. Chang, B.U., Kim, Y., \& Oh, J.J. (2011). The current status of NORM/TENORM industries and establishment of regu latory framework in Korea, Radiat. Prot. Dosim. 146 (1 3), art. no. ncr 140, pp. 170173

18. Shakhashiro, A., Sansone, U., Wershofen, H., Bollhöfer, A., Kim, C.K., Kim, C.S., Kis Benedek, G., Korun, M., Moune, M., Lee, S.H., Tarjan, S., \& Al Masri, M.S. (2011). The new IAEA reference material: IAEA 434 technologically enhanced naturally occurring radioactive materials (TENORM) in phos phogypsum, Applied radiation and isotope, 69, 231236.

19. Bolívar, J.P., Martín, J.E., García Tenorio, R., Pérez Moreno, J.P., \& Mas, J.L. (2009). Behaviour and fluxes of natural radionuclides in the production process of a phosphoric acid plant, Appl. Radiat. Isot., 67, 345356.

20. Gezer, F., Turhan, S., Uĝur, F.A., Gören, E., Kurt, M.Z., \& Ufuktepe, Y. (2010). Natural radionuclide content of dis posed phosphogypsum as TENORM produced from phosphorus fertilizer industry in Turkey, Ann. Nucl. Energy., 50, 3337.

21. Desideri, D., Roselli, C., Meli, M.A., \& Feduzi, L. (2008). Analytical methods for the characterization and the leach ability evaluation of a solid waste generated in a phos phoric acid production plant, Microchem. J., 88, 6773.

22. Stamatis, V., Seferlis, S., Kamenopoulou, V.; Potiriadis, C., Koukouliou, V., Kehagia, K., Dagli, C., Georgiadis, S., \& Camarinopoulos, L. (2010). Decommissioning a phos phoric acid production plant: A radiological protection case study, J. Environ. Radioact., 101, 10131023.

23. Kleinschmidt, R., \& Akber, R. (2008). Naturally occurring radionuclides in materials derived from urban water treat ment plants in southeast Queensland, Australia, J. Envi ron. Radioact., 99, 607620.

24. Al Masri, M.S., \& Shwiekani, R. (2008). Radon gas distri bution in natural gas processing facilities and workplace air environment, J. Environ. Radioact, 99, 574580.

25. Smith, K.P., Arnish, J.J., Williams, G.P., \& Blunt, D.L. (2003). Assessment of the disposal of radioactive petro leum industry waste in nonhazardous landfills using risk based modelling, Environ. Sci. Technol., 37, 20602066.

26. Attallah, M.F., Awwad, N.S., \& Aly, H.F. (2012). Environ mental radioactivity of TE NORM waste produced from petroleum industry in Egypt: Review on characterization and treatment, In Natural Gas Extraction to End Use, S. Borra Gupta (Ed.), InTech: Rijeka, Croatia, pp 7598.

27. Pereira, A.J.S.C., \& Neves, L.J.P.F. (2012). Estimation of the radiological background and dose assessment in areas with naturally occurring uranium geochemical anomalies A case study in the Iberian Massif (Central Portugal), J. Environ. Radioact., 112, 96107.

28. Chen, J., \& Liu, J. Study on sulphate and nitrate pollution in groundwater of a leaching uranium mine. Proceedings of 2 nd International Conference on Remote Sensing, Envi ronment and Transportation Engineering, RSETE 2012 , Nanjing, Jiangsu, China, art. no. 6260751.

29. Tokunaga, T.K., Kim, Y., \& Wan, J. (2009). Potential remediation approach for uranium contaminated ground waters through potassium uranyl vanadate precipitation, Environ. Sci. Technol, 43, 54675471.

30. Lv, J., Jia, F., Zhang, X., \& Feng, Z. Column experiments on remedy acid seepage water from U containing debris with PRB. Proceedings of International Conference on Remote Sensing, Environment and Transportation Engi neering, RSETE 2011 Nanjing, Jiangsu, China. art. no. 5965177, 39253929.

31. Crane, R.A., Dickinson, M., Popescu, I.C., \& Scott, T.B. (2011). Magnetite and zero valent iron nanoparticles for the remediation of uranium contaminated environmental water, Water Res, 45, 29312942.

32. Panturu, E., Groza, N., Filcenco Olteanu, A., Jinescu, G., \& Panturu, R. I. (2009). In situ decontamination of the mine waters from uranium mining activities Revista de Chimie 60, 13181323.

33. Klimkova, S., Cernik, M., Lacinova, L., Filip, J., Jancik, D., \& Zboril, R. (2011). Zero valent iron nanoparticles in treatment of acid mine water from in situ uranium leach ing. Chemosphere, 82, 11781184.

34. Gao, B., \& Lin, Y. (2010). Laboratory evaluation of permea ble reactive barriers to treat water impact by acid low level uranium drainage, Adv. Mater. Res., 113 116, 13421344.

35. Mategaonkar, M, \& Eldho, T.I. (2012). Groundwater remediation optimization using a point collocation method and particle swarm optimization, Environ. Mod ell. Softw., 32, 3748.

36. Shephard, E., Walter, N., Downey, H., Collopy, P., \& Conant, J. (2012). Remediation of uranium impacted sedi ments in a watercourse, Radwaste Solutions, 19, 1217. 
37. Hsu, L., Thacher, R., Yokota Joshi, A., Wong, A., Nealson, K.H., Pirbazari, M., \& Astani, S. Evaluation of a novel bio remediation process coupling an electrokinetic system with microbial fuel cell technology. Proceedings of 10AIChE 2010 AIChE Annual Meeting, Conference, 712 Nov. 2012. 723c.

38. Gye Nam, K., Dong Bin, S., Hye Min, P., Ki Won, L., \& Un Soo, C. (2011). Development of pilot scale electroki netic remediation technology for uranium removal, Sep. Purif. Technol., 80, 6772.

39. Kim, G. N., Shon, D. B., Park, H. M., Choi, W. K., \& Lee, K. W. (2011). The development of precipitation filtering technology for uranium electrokinetic Leachate, Sep. Purif. Technol., 79, 144150.

40. Vera Tomé, F., Blanco Rodríguez, P., \& Lozano, J.C. (2008). Elimination of natural uranium and 226Ra from contaminated waters by rhizofiltration using Helianthus annuus L., Sci. Total Environ., 393(2 3), 351357.

41. Kim, G. N., Kim, S.S., Park, H.M., Kim, W.S., Park, U.R., \& Moon, J.K. (2012). Remediation of soil/concrete conta minated with uranium and radium by biological method, J. Radioanal. Nucl. Chem., 18.
42. Cecal, A., Humelnicu, D., Rudic, V., Cepoi, L., Ganju, D., \& Cojocari, A. (2012). Uptake of uranyl ions from ura nium ores and sludges by means of Spirulina platensis, Porphyridium cruentum and Nostok linckia alga, Biore sour. Technol., 118, 1923.

43. Zhao, J., Scheibe, T.D., \& Mahadevan, R. (2011). Model based analysis of the role of biological, hydrological and geochemical factors affecting uranium bioremediation, Biotechnol. Bioeng., 108, 15371548.

44. Hildegarde, V. Phytoremediation options for radioactively contaminated sites evaluated, Ann. Nucl. Energy, 2013 http://dx.doi.org/10.1016/j.anucene.2013.02.005

45. International Atomic Energy Authority, Handbook of parameter values for the prediction of radionuclide trans fer in terrestrial and freshwater environments. TRS 472, IAEA: Vienna, Austria, 2010.

46. Bhagawatilal, J., \& Anubha, S. (2013). Optimization of chelators to enhance uranium uptake from tailings for phytoremediation, Chemosphere 91, 692696.

47. Prieto, C., Lozano, J.C., Blanco Rodriguez, P., \& Vera Tome, F. (2013). Enhancing radium solubilization in soils by citrate, EDTA, and EDDS chelating Amendments, J. Hazard. Mater, 250 251, 439446.

Post-print standardized by MSL Academic Endeavors, the imprint of the Michael Schwartz Library at Cleveland State University, 2017 